\title{
THE INFLUENCE OF INTANGIBLE ASSETS ON COMPANY PERFORMANCE
}

\author{
[Vliv nehmotných aktiv na výkonnost podniku] \\ Olga Hasprová ${ }^{1}, Z_{\text {deněk } \text { Brabec }^{2} \text {, Jiř́i Rozkovec }}^{3}$ \\ ${ }^{1}$ Technická univerzita v Liberci, Ekonomická fakulta, Studentská 1402/2, 46117 Liberec \\ Email:olga.hasprova@tul.cz \\ ${ }^{2}$ Technická univerzita v Liberci, Ekonomická fakulta, Studentská 1402/2, 46117 Liberec \\ Email:zdenek.brabec@tul.cz \\ 3 Technická univerzita v Liberci, Ekonomická fakulta, Studentská 1402/2, 46117 Liberec \\ Email:jiri.rozkovec@tul.cz
}

\begin{abstract}
Intangible assets play an increasingly important role in business management as their proportion on total assets is rising. Their recognition and measurement in financial statements is often complicated and is dependent on the requirements of a given accounting regulation. Intangible assets also influence company performance in a considerable way. Therefore, the aim of this article is to analyse the disclosure of intangible assets, as well as, the relationship between intangible assets and given ratios describing company performance. To do so financial statements of large companies located in selected regions of the Czech Republic, which were published in years 2010 - 2015, are analysed. The established hypotheses are tested using the methods of the trend analysis and the simple regression. The results of this research confirm that the amount of intangible assets disclosed by analysed companies does change over time. In addition to that, it can be concluded that the existence of intangible assets does positively influence company performance measured by the given ratios.
\end{abstract}

Keywords: big companies, company performance, Czech Republic, intangible assets.

JEL classification: M41, M48.

Received: 2.9.2018; Reviewed: 15.9.2018; 9.11.2018; Accepted: 6.3.2019

\section{Introduction}

Currently, the value of enterprises and their performance is not dependent on the value of their property, plant or equipment but it is rather influenced by the technology used, the knowledge of employees, protected trademarks, used patents, inventions etc. At the global level, the importance and the value of intangible assets is growing, not only in enterprises but also in the public sector, such as in research institutions, universities etc. For example, their share on total assets, as disclosed by US companies, has risen from about $5 \%$ in 1978 to approximately 75-85\% at present (Svoboda et al. 2017). This trend is especially based on the increased competition caused by globalization and deregulation of the economy (Lev 2001). However, the real value of intangible assets can be measured only if a company participates in a certain type of acquisition or merger (Sedláček et al. 2014), especially as the item "goodwill" in financial statements of the buyer (Colley \& Volkan 1998).

Nevertheless, many intangible assets, such as the value of research and development, patents, educated workforce, quality of company management, stability of supplier-customer relations cannot be recognized in financial statements although they have a significant impact on the market value of the company (Jáč et al. 2015; Svačina 2010). These assets are created within the company and are not intended to be sold. The recognition of such assets is very complicated because their economic benefits cannot be measured directly. Incorrect recognition of intangible assets usually causes a systematic undervaluation of companies 
using a large amount of intangible assets. (Sedláček 2010) On the other hand, Jones (2011) points out that "failing companies capitalize intangible assets more aggressively than nonfailed companies."

The issue of recognition and measurement of intangible assets is discussed quite substantially by foreign authors, especially the Anglo-Saxon ones, in comparison with the Czech authors. This is probably because companies located in these countries are used to disclose intangible assets more often. In addition, these companies use International Financial Reporting Standards or similar ones for the preparation of financial statements, which provides them with a more comprehensive set of guidelines for recognition and measurement of intangible assets, as compared to the Czech accounting legislation.

The article analyses intangible assets from the accounting perspective. Firstly, the disclosure of intangible assets in analysed companies is studied. Furthermore, the proportion between intangible assets and fixed assets is analysed over time. Moreover, based on the previous research performed by Hasprova et al. (2016) the authors try to find out the relationship between intangible assets and selected performance indicators.

\section{Literature review}

\subsection{Definition of intangible assets}

Intangible assets include various non-material assets that can be defined and monitored in various ways that often differ or, conversely, overlap. Lev (2001), for example, in accordance with the tradition of intellectual capital classifies intangible assets into four groups:

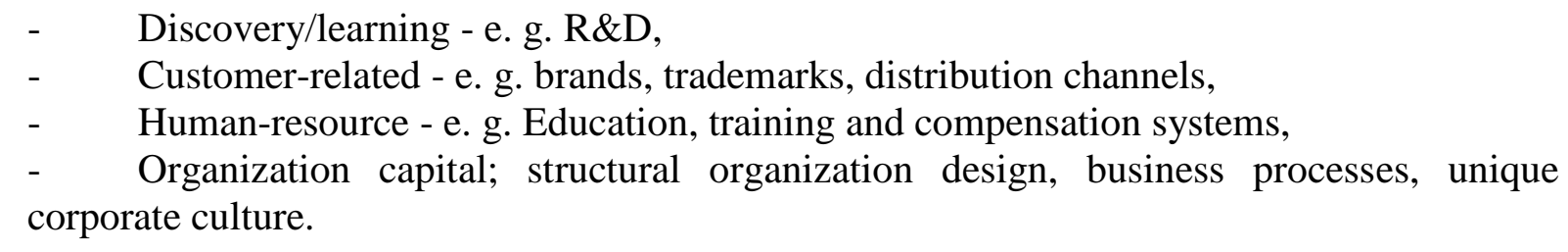

From the legal perspective, intangible assets are rather characterized as intellectual property or more precisely rights to intellectual property. Individual authors define intellectual property differently. Mingaleva \& Mirskikh (2013) define intellectual property in a very general matter as indicators of social, cultural and economic development of the state. According to Holyoak \& Torremans (2013), ,intellectual property rights are, first, property rights - but, secondly, they are property rights in something intangible; finally, they protect innovations and creations, and reward innovative and creative activity. " On the contrary, C̆ada (2009) explains intellectual rights as a narrower concept compared to intangible assets. Dobiás (2008), on the other hand, emphasizes the existence of the right to intellectual property, which may only be an object of a sale, gift, deposit, inheritance or other transfer. Candelin-Palmqvist et al. (2012) highlight the complexity and variety of questions related to intellectual property and, above all, their dependence on different legal regulations in each country.

Intellectual property, therefore, reflects the legal existence and economic value that are important attributes of intangible assets. Despite the different definitions of the term intellectual property, it is clear that intellectual property rights can provide companies and other entities with new earnings and, therefore, they are a tool for increasing their competitiveness (Blomquvist et al. 2004). 
Considering the macroeconomic perspective, the basic ratio used for the measurement of intangible assets is the share of R \& D expenditures to GDP (Trexler 2017). As stated in the "Lisbon Strategy", the proportion of R \& D expenditures to GDP should be at a minimum of $3 \%$. But the study of Helmers et al. (2009) found out that between 1995 and 2007 the average proportion in the EU was only about $1.2 \%$. According to Nakamura (2001), in the year 2000 the value of U.S. corporate investment into intangible assets was about $\$ 1.0$ trillion which was about the same amount as invested in property, plant, and equipment. Furthermore, the share of intangible assets compared to total assets is rising. In addition to that, Hall \& Kim (2000) estimates the total value of intangible capital as ranging between half to two-thirds of the total market value of publicly traded corporations, as indicated by the $q$ ratio (market value to replacement cost of physical assets) Furthermore, intangible assets contribute to the economic growth in a considerable way. Corrado et al (2009), for example, claim that only $8 \%$ of economic growth can attributed to traditional basic capital investment.

\subsection{Intangible assets in financial accounting}

Monitoring and analysing intangible assets held by business entities has become the world's standard approach in recent years. Individual approaches can be found in studies performed by Smith (1996), Lev (2001), or Salojärvi et al. (2005). When determining the value of intangible assets used in companies, the accounting value of intangible assets is used in most cases. Therefore, it is necessary to consider the influence of a given accounting system according to which the financial statements are prepared. The requirements of individual accounting systems usually differ in the areas of recognition and measurement of intangible assets or by determination of their direct or indirect influence on the performance and value of a company (Stolowy \& Jeny-Cazavan 2001).

The recognition of internally generated intangible assets is especially complicated. The broadly discussed question is if it should be allowed:

- to recognize internally generated intangible assets in the balance sheet whenever certain criteria are met,

- $\quad$ to recognize expenditure on all internally generated intangible assets in the balance sheet as an expense,

- $\quad$ to generally recognize expenditure on all internally generated assets as an expense, with certain specified exceptions.

To deal with the above-mentioned problems Lev (2003) proposes, for example, the preparation of a "new comprehensive balance sheet" that will provide investors with information about company's financial situation, both with and without the capitalization of intangible assets. Another contribution to this discussion is the "invisible balance sheet" developed by Sveiby (1989) that should help companies to present their personnel in a more informative way. The incorporation of not yet reported items of intangible assets in financial statements is also proposed by Wyatt \& Abernethy (2003).

The above-mentioned techniques should remove the information asymmetry between company management and external users of company's financial statements. If such information is not publicly available, the value of companies is usually determined based on the estimates of financial analysts. Such estimates are, however, dependent on their ability to measure the future benefits from the use of intangible assets ( $\mathrm{Gu} \&$ Wang 2005).

Currently, many European companies prepare a report containing information about their intangible assets or intellectual capital on a voluntarily basis. This approach reduces to a large 
extent the gap between the book and the market value of a company (Krstić \& Dordević 2010).

International Financial Reporting Standards (IFRS) allow the recognition of intangible assets only if they meet the definition of intangible assets contained in the conceptual framework. So this item must be controlled by the company, it is a result of past events and its economic benefits will flow to the company. Furthermore, the economic benefits (sale or use of intangible assets) associated with this item must be probable and the cost or value of the item must be measured reliably. IAS 38 requires another critical attribute for recognition of an intangible asset that is called identifiability. It means that the intangible asset must be separable, so it is capable to be sold, transferred, licensed, rented, or exchanged to be separable and furthermore, this intangible asset arises from contractual or other legal rights (IASB 2014).

On the contrary to that, Czech accounting legislation does not provide any general definition of intangible assets but only an explicit list of items that can be recognized as intangible assets, as well as, a list containing items that cannot be recognized as intangible assets (Hasprová \& Brabec 2014; Kř́žová 2016). There is no economic justification of their content, so the legislation is not able to provide a relevant guideline that should help prepare financial statements. An item is recognized as a fixed intangible asset if its useful life exceeds one year and the acquisition cost exceeds the value limit specified by the company. Useful life is described as a period during which the asset can be used itself or may serve as a basis for the component of other procedures and solutions (Malíková \& Černíková 2013).

Moreover, the recognition of intangible assets in progress is a bit controversial. This issue is related to the value attributable to the costs spent on the development of these assets. The problem is that a company does not know whether the assets will be marketable in the future. Therefore, there is no proof that they will provide sufficient profits to cover the cost invested in their creation. Considering the principle of accrual accounting, it would be more appropriate to recognize these assets as expenses of the current accounting period. These assets may be potentially recognised once they have been completed and only if they meet the required conditions for their recognition (Sedláček 2010).

\subsection{Intangible assets influencing company performance}

In the literature, various authors suggest different ways of measuring the influence of intangible assets on company performance. For example, Clausen \& Hirth (2016) developed a new ratio measuring intangible intensity. Their Return on tangible assets (ROTA) should be used as a proxy that enables to express the productivity of already existing intangibles. It should also serve as an additional factor explaining company value, measured either as market capitalization or acquisition prices in M\&A transactions. Moreover, it captures the increasing importance of intangibles over time.

Similarly, Lev (2004) speaks about intangible driven earnings. According to him, the value of intangible capital is derived by subtracting the average contribution of physical and financial assets from earnings. The remaining part expresses the contribution of intangible assets to the company's performance and that provides the basis for the valuation of intangible capital. Subsequently, intangible capital is calculated by computing the present value of the forecasted stream of intangible-driven earnings. Moreover, the comprehensive value of an enterprise can be calculated. This measure is used to evaluate stock prices of companies. Comprehensive 
value would be the net value of physical and financial assets plus the missing part - intangible capital.

The amount of intangible assets disclosed in financial statements may be also used for evaluating the performance of entities operating in the public sector. According to Hasprová et al. (2018), the value of intangible assets may be, under certain conditions, used to measure the performance of Czech public universities.

\section{Methodology}

The aim of the article is to test the above-mentioned statements related to the disclosure of intangible assets within the reality in the Czech Republic. For that purpose, the following hypotheses are set:

H1 The amount of disclosed intangible assets does not change over time.

H2 The share of disclosed intangible assets to total fixed assets does not change over time.

H3 The amount of disclosed intangible assets does not influence company performance.

The above-mentioned hypotheses are tested using the data presented by companies located in selected regions of the Czech Republic. As the source of the data, the database Bisnode Magnus web is used. The research sample is geographically determined by the NUTS 2 Region Northeast, which consists of Regions Hradec Králové, Pardubice and Liberec.

Based on the assumption that intangible assets are more prevalent in large enterprises the research sample is further limited only on large companies that were active in years $2010-$ 2015. The category "large company" as defined by the Accounting Act no 563/1991 Coll. includes companies that on the balance sheet date exceed at least two of the following limits:

- $\quad$ total net assets over 500,000,000 CZK,

- $\quad$ annual net turnover over 1,000,000,000 CZK,

- $\quad$ the average number of employees during the accounting period over 250.

In addition to that, the following subjects are excluded from the research sample:

- $\quad$ public interest entities (banks, savings banks, credit unions, insurance, and reinsurance companies and pension funds),

- $\quad$ selected entities defined by a special law (governmental agencies, state funds, territorial self-governing units, local authorities, Regional Councils of Cohesion Regions, contributory organizations and health insurance companies).

The data are obtained from annual financial statements covering 12 consecutive months corresponding to a calendar or business year. Intangible assets are classified according to the rules of decree 500/2002 Coll. that sets the rules for business entities.

Based on the above-mentioned restrictive conditions the research sample contains 126 large companies that published their financial statements for every period between 2010 and 2015 . Recent data are not available, because the vast majority of the research sample failed to comply with legal requirements and did not publish the financial statements for the year 2016 till the end of 2017. More specifically, the research sample contains 51 companies in the Pardubice region, 35 companies in the Hradec Králové Region and 40 companies in the Liberec Region. The branch structure of the research sample is shown in Table 1. 
Table 1: The branch structure of the research sample

\begin{tabular}{|c|c|c|c|c|c|c|c|c|c|}
\hline \multirow{2}{*}{ Region } & \multicolumn{8}{|c|}{ Branch } & \multirow{2}{*}{ Total } \\
\hline & A & B & $\mathrm{C}$ & $\mathrm{D}$ & $\mathrm{E}$ & $\mathrm{F}$ & G & $\mathrm{H}$ & \\
\hline Pardubice Region & 4 & 0 & 36 & 2 & 0 & 2 & 6 & 1 & 51 \\
\hline $\begin{array}{l}\text { Hradec Králové } \\
\text { Region }\end{array}$ & 0 & 0 & 26 & 0 & 1 & 0 & 6 & 2 & 35 \\
\hline Liberec Region & 0 & 1 & 34 & 0 & 0 & 1 & 2 & 2 & 40 \\
\hline Total & 4 & 1 & 96 & 2 & 1 & 3 & 14 & 5 & 126 \\
\hline
\end{tabular}

Source: Own elaboration.

The branches are classified according to the CZ NACE where:

A - Agriculture, forestry, fishing

$\mathrm{B}$ - Mining and quarrying

$\mathrm{C}$ - Manufacturing

D - Electricity, gas, steam and air conditioning supply

E - Water supply; sewerage, waste management, and remediation activities

$\mathrm{F}$ - Construction

$\mathrm{G}$ - Distributive Trades

$\mathrm{H}$ - Transportation and storage services

Based on the above-mentioned data it is obvious that manufacturing industry prevails in all regions. In the Pardubice Region, its share is $70.6 \%$, in the Hradec Králové Region it makes $74.2 \%$ and in the Liberec Region it is $85 \%$. For the whole NUT2 Region Northeast, the share of the manufacturing industry is $76.2 \%$.

Considering the legal form of companies embodied in the research sample the prevailing form is the limited liability partnership (53.17\%), followed by joint-stock company (42.06\%). Limited partnership (1.59\%) and Cooperative (3.17\%) represent only a minor part of analysed companies. A detailed structure of the research sample reflecting the legal of companies is shown in table 2 .

Table 2: The structure of the research sample according to the legal form

\begin{tabular}{|l|c|c|c|c|c|}
\hline \multirow{2}{*}{ Region } & \multicolumn{5}{|c|}{ Company type } \\
\cline { 2 - 6 } & $\begin{array}{c}\text { Joint-stock } \\
\text { company }\end{array}$ & $\begin{array}{c}\text { Limited liability } \\
\text { company }\end{array}$ & $\begin{array}{c}\text { Limited } \\
\text { partnership }\end{array}$ & Cooperative & Total \\
\hline Pardubice Region & 20 & 27 & 0 & 4 & 51 \\
\hline Hradec Králové Region & 21 & 14 & 0 & 0 & 35 \\
\hline Liberec Region & 12 & 26 & 2 & 0 & 40 \\
\hline Total & 53 & 67 & 2 & 4 & 126 \\
\hline
\end{tabular}

Source: Own elaboration.

Firstly, the amount of intangible assets disclosed by the analysed companies is studied. For that purpose, the methods of descriptive statistics are used. Then, the situation is analysed from the time perspective. To do so, the trend analysis suggesting the linear model for forecasting the amount of intangible assets in future periods is used.

Subsequently, the influence of intangible assets on company performance is studied. For the evaluation of company performance, the following absolute measures are used: the amount of sales of goods and merchandise sold, Earnings after Taxes (EAT), Earnings before Interest and Taxes (EBIT) and Earnings before Interest, Taxes, Depreciation and Amortization (EBITDA). All of these measures are expressed at current prices. To test the relationship between intangible assets and the above-mention performance measures the method of simple regression is used. 
The net value of assets is measured at historical cost. Authors, intentionally, do not convert the values at historical cost to real prices using the consumer price index published by the Czech statistical office. According to the authors, the asset structure disclosed by business entities differs significantly from the items included into the consumer basket used for the calculation of the consumer price index. The conversion would, therefore, replace one price distortion by another.

\section{Empirical results and discussion}

The following analysis of intangible assets disclosed by selected companies prefers using a holistic approach. It also reflects the geographic structure of the research sample as well as the requirements of the Czech accounting legislation.

\subsection{Intangible assets disclosed by selected companies}

Firstly, the actual amount of companies disclosing intangible assets is analysed (see table 3 ). The columns express, firstly, absolute frequencies and, then, the relative frequencies in individual years. Last column shows the average values for the whole analysed period.

Table 3: Number of companies disclosing intangible assets

\begin{tabular}{|c|c|c|c|c|c|c|c|c|c|c|c|c|c|c|}
\hline \multirow{3}{*}{ Region } & \multicolumn{12}{|c|}{ Years } & \multirow{2}{*}{\multicolumn{2}{|c|}{ Average }} \\
\hline & \multicolumn{2}{|c|}{2010} & \multicolumn{2}{|c|}{2011} & \multicolumn{2}{|c|}{2012} & \multicolumn{2}{|c|}{2013} & \multicolumn{2}{|c|}{2014} & \multicolumn{2}{|c|}{2015} & & \\
\hline & $\mathrm{n}_{\mathrm{i}}$ & $\mathrm{p}_{\mathrm{i}}$ & $\mathrm{n}_{\mathrm{i}}$ & $\mathrm{p}_{\mathrm{i}}$ & $\mathrm{n}_{\mathrm{i}}$ & $\mathrm{p}_{\mathrm{i}}$ & $\mathrm{n}_{\mathrm{i}}$ & $\mathrm{p}_{\mathrm{i}}$ & $\mathrm{n}_{\mathrm{i}}$ & $\mathrm{p}_{\mathrm{i}}$ & $\mathrm{n}_{\mathrm{i}}$ & $\mathrm{p}_{\mathrm{i}}$ & $\mathrm{n}_{\mathrm{i}}$ & $\mathrm{p}_{\mathrm{i}}$ \\
\hline $\begin{array}{l}\text { Pardubice } \\
\text { Region }\end{array}$ & 47 & 0.92 & 48 & 0.94 & 49 & 0.96 & 47 & 0.92 & 49 & 0.96 & 48 & 0.94 & 48 & 0.94 \\
\hline $\begin{array}{l}\text { Hradec Králové } \\
\text { Region }\end{array}$ & 31 & 0.89 & 32 & 0.91 & 31 & 0.89 & 32 & 0.91 & 33 & 0.94 & 30 & 0.86 & 32 & 0.90 \\
\hline Liberec Region & 38 & 0.95 & 38 & 0.95 & 36 & 0.90 & 34 & 0.85 & 36 & 0.90 & 37 & 0.93 & 37 & 0.91 \\
\hline
\end{tabular}

Source: Own elaboration.

As shown in table 3, most of the analysed companies disclose intangible assets in all periods. The research findings are completely different from the findings of Sabolovič (2011) who claims that only $7 \%$ of companies from his research sample disclosed intangible assets for the whole period.

Secondly, the value of total intangible assets disclosed by analysed companies is studied. In order to reflect the size of companies the amount of intangible assets is divided by the number of employees. In the Hradec Králové Region at the $95.0 \%$ confidence level it can be concluded that amount of disclosed intangible assets does not change over time because the Pvalue for the linear term is greater than 0.05 (see table 4). On the other hand, in the Liberec Region the P-value for the linear term is less than 0.05 , so the amount of disclosed intangible assets does change over time. More precisely, the amount of intangible assets per employee has a declining trend that can be expressed with the following forecast model:

$$
\mathrm{y}_{\mathrm{t}}=21,138,000-10,453 \mathrm{t}
$$

In the Pardubice Region, however, the situation is opposite as intangible assets per employee have an increasing trend that can be expressed with the following forecast model:

$$
\mathrm{y}_{\mathrm{t}}=-20,537,000+10,169.9 \mathrm{t}
$$


Based on the above-mentioned results the hypothesis $\mathrm{H} 1$ can be rejected at the $95.0 \%$ confidence level in both Liberec and Pardubice Region, whereas in Hradec Králové Region this hypothesis is valid.

Table 4: Test of hypothesis H1

\begin{tabular}{|l|c|c|}
\hline \multirow{2}{*}{ Region } & \multicolumn{2}{|c|}{ Parameter P-Value } \\
\cline { 2 - 3 } & Constant & Slope \\
\hline Pardubice Region & 0.0069 & 0.0068 \\
\hline Hradec Králové Region & 0.2383 & 0.2344 \\
\hline Liberec Region & 0.0393 & 0.0395 \\
\hline
\end{tabular}

Source: Own elaboration.

Thirdly, the importance of intangible assets is measured using the ratio of intangible assets to tangible assets. In both Hradec Králové and Pardubice Region at the 95.0\% confidence level, it can be concluded that the share of disclosed intangible assets to total fixed assets does not change over time since the P-value for the linear term is greater than 0.05 (see table 5). On the other hand, in the Liberec Region the P-value for the linear term is less than 0.05, so the share of disclosed intangible assets to total fixed assets does change over time. Therefore, it can be concluded that the ratio of intangible assets to tangible assets has a declining trend that can be expressed with the following forecast model:

$$
\mathrm{y}_{\mathrm{t}}=9.2419-0.0046 \mathrm{t}
$$

These results show that the hypothesis $\mathrm{H} 2$ can be rejected at the $95.0 \%$ confidence level only in the Liberec region, whereas in both Hradec Králové and Pardubice this hypothesis is valid.

Table 5: Test of hypothesis H2

\begin{tabular}{|l|c|c|}
\hline \multirow{2}{*}{ Region } & \multicolumn{2}{|c|}{ Parameter P-Value } \\
\cline { 2 - 3 } & Constant & Slope \\
\hline Pardubice Region & 0.1076 & 0.1057 \\
\hline Hradec Králové Region & 0.2089 & 0.2058 \\
\hline Liberec Region & 0.0001 & 0.0001 \\
\hline
\end{tabular}

Source: Own elaboration.

And fourthly, the structure on intangible assets disclosed by selected companies is analysed using the arithmetic average, standard deviation and the number of companies disclosing individual items of intangible assets. As in the previous analysis, all individual items are divided by the number of employees. All three ratios are calculated on the basis of the data of all companies covering the whole analysed period. Therefore, for the six-year period the data contain 306 items in the Pardubice Region, 210 items in the Hradec Králové Region and 240 items in the Liberec Region. Based on the data presented in table 6, it can be concluded that in the Pardubice Region the highest share in absolute terms represent Other intangible assets and Valuable rights. In the Hradec Králové Region the most important items in absolute terms are Valuable rights and Intangible results of research and development. And in the Liberec Region the most important items include Intangible results of research and development and Other intangible assets. The structure of intangible assets is mostly influenced by a handful of companies that disclose a large sums of individual items in the Region. This is especially the case of Intangible results of research and development that are disclosed by only slightly more than $8 \%$ of analysed companies in the Pardubice Region, respectively by a bit more than $11 \%$ of companies in the Liberec Region. The mostly disclosed item is the Software but its value in absolute terms is not very important. 
Table 6: The structure of intangible assets

\begin{tabular}{|c|c|c|c|c|c|c|c|c|c|}
\hline \multirow[b]{2}{*}{$\begin{array}{c}\text { Type of } \\
\text { intangible } \\
\text { assets }\end{array}$} & \multicolumn{3}{|c|}{ Pardubice Region } & \multicolumn{3}{|c|}{ Hradec Králové Region } & \multicolumn{3}{|c|}{ Liberec Region } \\
\hline & Average & $\begin{array}{l}\text { Standard } \\
\text { deviation }\end{array}$ & $\begin{array}{c}\text { Number of } \\
\text { disclosing } \\
\text { companies } \\
\text { in } \%\end{array}$ & Average & $\begin{array}{l}\text { Standard } \\
\text { deviation }\end{array}$ & $\begin{array}{c}\text { Number of } \\
\text { disclosing } \\
\text { companies } \\
\text { in } \%\end{array}$ & Average & $\begin{array}{l}\text { Standard } \\
\text { deviation }\end{array}$ & $\begin{array}{c}\text { Number of } \\
\text { disclosing } \\
\text { companies } \\
\text { in } \%\end{array}$ \\
\hline $\begin{array}{l}\text { Formation } \\
\text { expenses }\end{array}$ & 2.53 & 19.92 & 2.94 & 0 & 0 & 0 & 2.52 & 34.27 & 1.25 \\
\hline $\begin{array}{l}\text { Intangible } \\
\text { results of } \\
\text { research and } \\
\text { development }\end{array}$ & 7,891 & 57,57 & 8.17 & 16,145 & 97,415 & 4.25 & 16,359 & 80,977 & 11.25 \\
\hline Software & 6,199 & 14,284 & 89.87 & 3,665 & 6,146 & 87.62 & 3,524 & 5,979 & 87.92 \\
\hline $\begin{array}{l}\text { Valuable } \\
\text { rights }\end{array}$ & 10,441 & 50,358 & 27.45 & 23,846 & 141,911 & 19.52 & 1,406 & 9,245 & 12.92 \\
\hline Goodwill & 6,210 & 62,737 & 1.63 & $-1,090$ & 9,57 & 2.38 & -11.83 & 183.29 & 0.42 \\
\hline $\begin{array}{l}\text { Other } \\
\text { intangible } \\
\text { assets }\end{array}$ & 17,189 & 116,478 & 22.25 & 5,581 & 38,737 & 10.00 & 9,330 & 14,616 & 11.67 \\
\hline $\begin{array}{l}\text { Intangible } \\
\text { assets in } \\
\text { progress, } \\
\text { Advances paid } \\
\text { on intangible } \\
\text { assets }\end{array}$ & 13,348 & 139,241 & 40.52 & 16,279 & 88,019 & 40.95 & 7,892 & 46,422 & 30.83 \\
\hline $\begin{array}{l}\text { Total } \\
\text { intangible } \\
\text { assets }\end{array}$ & 61,281 & $229,251,19$ & 94.12 & 64,426 & $231,268,91$ & 90.00 & 38,502 & $16,0862,47$ & 91.25 \\
\hline
\end{tabular}

Source: Own elaboration.

\subsection{The influence of intangible assets on company performance}

To analyse the influence of intangible assets on company performance the regression model describing the relationship between intangible assets as independent variable and selected performance indicators (Sales, EBITDA, EBIT, EAT) as dependent variable is established. The absolute indicators of company performance are selected because of their crucial importance in measuring company performance. All the following analyses are performed assuming a linear relationship existing between a given dependent variable and intangible assets as the independent variable (see table 7).

In the Liberec Region at the $95.0 \%$ confidence level it can be concluded that the amount of disclosed intangible assets does not influence company performance since the P-value for the linear term is greater than 0.05 (see table 8). On the other hand, in both the Hradec Králové and Pardubice Region the P-value for the linear term is less than 0.05 and, therefore, amount of disclosed intangible assets does influence company sales. Table 7 contains the equation of the fitted model for these two regions. The potential impact of the autocorrelation of residues has been ruled out, since for all analysed regression models the value of the Durbin-Watson statistics oscillates around 2. 
Table 7: The equation of corresponding linear models

\begin{tabular}{|l|l|l|}
\hline \multirow{2}{*}{ Model for } & \multicolumn{2}{|c|}{ Region } \\
\cline { 2 - 3 } & \multicolumn{1}{|c|}{ Pardubice Region } & \multicolumn{1}{c|}{ Hradec Králové Region } \\
\hline Sales & Sales $=3,734,770+15.8278 *$ Intangible assets & Sales $=1,843,470+5.5054 *$ Intangible assets \\
\hline EAT & EAT $=98,981.7+0.9772 *$ Intangible assets & EAT $=107,510+0.0786 *$ Intangible assets \\
\hline EBIT & EBIT $=128,154+1.2254 *$ Intangible assets & EBIT $=137,695+0.1493 *$ Intangible assets \\
\hline EBITDA & EBITDA $=222,825+1.6098 *$ Intangible assets & EBITDA $=222,118+0.702 *$ Intangible assets \\
\hline
\end{tabular}

Source: Own elaboration.

Table 8: Test of hypothesis H3

\begin{tabular}{|l|c|c|c|c|c|c|c|c|}
\hline \multirow{2}{*}{ Region } & \multicolumn{2}{|c|}{ Sales } & \multicolumn{2}{c|}{ EAT } & \multicolumn{2}{c|}{ EBIT } & \multicolumn{2}{c|}{ EBITDA } \\
\cline { 2 - 10 } & F-Ratio & P-Value & F-Ratio & P-Value & F-Ratio & P-Value & F-Ratio & P-Value \\
\hline Pardubice Region & 7.46 & 0.0067 & 124.86 & 0.0000 & 137.13 & 0.0000 & 110.73 & 0.0000 \\
\hline $\begin{array}{l}\text { Hradec Králové } \\
\text { Region }\end{array}$ & $1,898.61$ & 0.0000 & 35.77 & 0.0000 & 87.03 & 0.0000 & $1,115.29$ & 0.0000 \\
\hline Liberec Region & 0.00 & 0.9965 & 0.03 & 0.8566 & 0.00 & 0.9993 & 0.21 & 0.6477 \\
\hline
\end{tabular}

Source: Own elaboration.

Based on the data shown in table 8 the hypothesis $\mathrm{H} 3$ can be rejected at the $95.0 \%$ confidence level in both Hradec Králové and Pardubice Region. In both regions, company performance does increase since the amount of intangible assets disclosed by given companies is rising. On the contrary, in Liberec Region this hypothesis is valid. The analysis also suggests that the most robust relationship is between intangible assets and sales respectively EBITDA because according to the R-Squared statistics (adjusted for d. f.) these models as fitted explain about $90 \%$ of the variability in sales respectively EBITDA.

\section{Conclusion}

Currently, the issues of intangible assets have to be handled carefully as their recognition in financial statements is increasingly important. Intangible assets play an important role in determining the value of a company at the time of sales or mergers. The value of intangible assets is equally important considering their sale or lease. From this point of view, the research shows that more than $90 \%$ of large companies embodied in the research sample disclose at least some items of intangible assets.

Considering the development of the amount of disclosed intangible assets over the analysed period, the absolute and relative value of disclosed total intangible assets does not change taken into account companies located in the Hradec Králové Region. In the Liberec Region, however, it has a decreasing trend both in absolute and relative terms. In the Pardubice Region using the absolute measure intangible assets are rising over time but in relative terms, there is no trend.

Analysing the influence of the amount of disclosed intangible assets on company performance it can be stated that in the Liberec Region intangible assets do not influence any of the selected ratios used to measure company performance. On the other hand, in the Hradec Králové and Pardubice Region, there is a significant relationship between the amount of intangible assets disclosed by large companies and their performance. Based on that, it can be concluded that the existence of intangible assets does positively influence company performance measured by the given ratios. The strongest relationship exists between intangible assets and sales respectively EBITDA.

To obtain a broader picture describing the influence of disclosed intangible assets on company performance, either the research sample shall be extended to the remaining regions of the 
Czech Republic or the analysis shall be focused on, for example, medium-sized or even small companies. Both these approaches shall include more companies into the research sample.

\section{Acknowledgement}

This paper was created in accordance with the institutional support for the conceptual development the Technical University of Liberec, Faculty of Economics - Project: Excellent Research Teams - NEW APPROACHES FOR THE REPORTING OF INTELLECTUAL ASSETS IN THE CZECH ENVIRONMENT (Excelentní výzkumné týmy - NOVÉ PŘÍSTUPY K VYKAZOVÁNÍ NEHMOTNÝCH AKTIV V PROSTŘEDÍ ČR)

\section{References}

[1] BLOMQUVIST, K. et al., 2004. Towards Networked R\&D Management: The R\&D Approach of Sonera Corporation as an Example, R\&D Management, 34(5), 591-603. ISSN 1467-9310.

[2] CANDELIN-PALMQVIST, H., B. SANDBERG and U. MYLLY, 2012. Intellectual property rights in innovation management research: A review, Technovation, 32(9-10), 502-512. ISSN 0166-4972.

[3] CLAUSEN, S. and S. HIRTH, 2016. Measuring the value of intangibles. Journal of Corporate Finance, 40(2016), 110-127. ISSN 0929-1199.

[4] COLley, J. R. and A. G. VOLKAN, 1988. Accounting for goodwill, Accounting Horizons, 2(1), 35-41. ISSN 0888-7993.

[5] CORRADO, C., C. HULTEN and D. SICHEL, 2009. Intangible capital and US economic growth. Review of income and wealth, 55(3), 661-685. ISSN 1475-4991.

[6] ČADA, K., 2009. Oceňování nehmotného majetku. Praha: Oecomica. ISBN 978-80-2451187-0.

[7] DOBIÁŠS, I., 2008. Vádemékum komercializace poznatků výzkumu a vývoje. Praha: Czech Knowledge Transfer Office při Inženýrské akademii ČR a Svaz průmyslu a dopravy ČR. ISBN 978-80-254-3305-8.

[8] GU, F. and W. WANG, 2005. Intangible Assets, Information Complexity, and Analysts' Earnings Forecasts. Journal of Business Finance \& Accounting, 32(9\&10), 1673-1702. ISSN 1468-9957.

[9] HALL, B. H. and D. KIM, 2000. Valuing Intangible Assets: The Stock Market Value of $R \& D$ Revised, Working Paper, Berkeley, CA and Cambridge, MA: University of California at Berkeley and Harvard University.

[10] HASPROVÁ, O. et al., 2016. Výkonnost podniku v závislosti na účetních, finančních a daňových faktorech. Liberec: Technická univerzita v Liberci. ISBN 978-80-7494-309-6.

[11] HASPROVÁ, O. and Z. BRABEC, 2014. The Importance of Intangible Assets in a Company Engaged in the Development of Advanced Technologies. Proceedings of the SGEM International Multidisciplinary Scientific Conferences on Social Sciences and Arts SGEM 2014, Volume II., 769-776. ISBN 978-619-7105-26-1.

[12] HASPROVÁ, O., Z. BRABEC and J. ROZKOVEC, 2018. Intangible assets disclosed by public universities in Czech Republic. Journal of International Studies, 11(1), 67-79. ISSN 2306-3483.

[13] HELMERS, C., C. SCHULTE and H. STRAUSS, 2009. Business R\&D expenditure and capital in Europe, EIB Papers, 14(1), 36-61. , ISSN 0257-7755 
[14] HOLYOAK, J. and P. TORREMANS, 2013. Intellectual Property Law. Hampshire: Oxford University Press. ISBN 978-0-19-964331-8.

[15] IASB, 2014, International accounting standard 38: Intangible assets, London: IASCF.

[16] JAC, I., J. SEDLAR and A. ZAYTSEV, 2015. Specificity of Forming the Incremental Value of a High-Technology Enterprise on the Basis of Implementing Innovative Managerial Techniques. Proceedings of the 12th International Conference Liberec Economic Forum, 272-285. ISBN 978-80-7494-225-9.

[17] JONES, S., 2011. Does the Capitalization of Intangible Assets Increase the Predictability of Corporate Failure? Accounting Horizons, 25(1), 41-70. ISSN 0888-7993.

[18] KRIZOVA, Z., 2016. Reporting of Intangibles in Different Reporting Systems. Proceedings of the 3rd International Multidisciplinary Scientific Conferences on Social Sciences and Arts SGEM 2016, Volume III., 321-328. ISBN 978-619-7105-74-2.

[19] KRSTIC, J. and M. DORDEVIC, 2010. Financial Reporting on Intangible Assets: Scope and Limitations. Economics and Organization, 7(3), 335-348. ISSN 0354-4699.

[20] LEV, B., 2001. Intangibles: Management, Measurement, and Reporting. Washington D.C.: Brookings Institution Press. ISBN 978-0-81-570093-7.

[21] LEV, B., 2003. Remarks on the Measurement, Valuation, and Reporting of Intangible Assets. Economic Policy Review, 2003(Sep), 17-22.

[22] LEV, B., 2004. Sharpening the Intangible Edges, Harvard Business Review, 82(6), 109116. ISSN 0017-8012.

[23] MALÍKOVÁ, O. and M. ČERNÍKOVÁ, 2013. Environmental Impact Identified from Company Accounts in the Czech Republic, WIT Transactions on Ecology and the Environment, 179, pp. 695 - 703. ISSN 1743-3541.

[24] MINGALEVA, Z. and I. MIRSKIKH, 2013. The Problems of Legal Regulation and Protection of Intellectual Property. Procedia-Social and Behavioral Sciences, 81, 329333. ISSN 1877-0428.

[25] NAKAMURA, L. I., 2001. What is the US Gross Investment in Intangibles?:(at Least) One Trillion Dollars a Year! Federal Reserve Bank of Philadelphia

[26] SABOLOVIC, M., 2011. Kvantitativní analýza trendu vývoje hodnoty nehmotného majetku v České republice. Ekonomický časopis, 59(10), 1018-1032. ISSN 0013-3035.

[27] SALOJÄRVI, S., P. FURU, and K. E. SVEIBY, 2005. Knowledge management and growth in Finnish SMEs. Journal of knowledge management, 9(2), 103-122. ISSN 13673270 .

[28] SEDLACEK, J., 2010. Analysis of the Development of Intangible Assets in the Czech Enterprises and their Impact on Financial Position and Performance. Ekonomickýčasopis, 58(4), 375-391. ISSN 0013-3035.

[29] SEDLACEK, J., P. VALOUCH, E. HYBLOVA and Z. KRIZOVA, 2014. Changes in Property and Ownership Structure of Companies as a Consequence of Mergers in the Czech Republic. InzinerineEkonomika-Engineering Economics, 25(2), 152-159. ISSN 2029-5839.

[30] SMITH, G. V., 1996. Trademark Valuation. New York: John Wiley\&Sons. ISBN 9780-47-114112-9. 
[31] SVEIBY, K. E., 1989. The Invisible Balance Sheet. Stockholm: Affarfgarblen. ISBN 9185804-22-3.

[32] SVOBODA, P., H. BOHUSOVA and L. SEMERADOVA, 2017. Intangible assets in Pharmaceutical Companies in the Czech Republic. Proceedings of the 14th International Scientific Conference European Financial Systems 2017, Part 2.,391-399. ISBN 978-80210-8609-8.

[33] STOLOWY, H. and A. JENY-CAZAVAN, 2001. International accounting disharmony: the case of intangibles. Accounting, Auditing and Accountability Journal, 14(4), 477-496. ISSN 0951-3574.

[34] TREXLER J., 2017. Indexy spotřebitelských cen v roce 2016. Statistika a my, 2017(2), 14-15. ISSN 1804-7149.

[35] WYATT, A. and M. A. ABERNATHY, 2003. Framework for Measurement and Reporting on Intangible Assets. Working Paper No. 12/03. Intellectual Property Research Institute of Australia, Melbourne. ISSN 1447-2315. 